\title{
Water quality parameters and aquatic insect diversity in Aahoo stream, southwestern Nigeria
}

\author{
Babasola Williams Adu and Emmanuel Ayobami Oyeniyi ${ }^{*}$ (D)
}

\begin{abstract}
Background: The role of water in the maintenance of an aquatic ecosystem is indispensable. In this study, aquatic insect biodiversity and the physico-chemical parameters of Aahoo stream, in southwestern Nigeria, were investigated from March to August 2017. Seven physico-chemical parameters were examined in six study sites.

Results: There were significant effects $(p<0.0001)$ of flow rate $\left(F_{5,12}=2221.9\right)$, electrical conductivity $\left(F_{5,12}=276.3\right)$, air temperature $\left(F_{5,12}=110.3\right)$, water temperature $\left(F_{5,12}=55.5\right)$ and $\mathrm{pH}\left(F_{5,12}=31.45\right)$ on the quantity of aquatic insects at the study sites in Aahoo stream. Dissolved oxygen $\left(F_{2,12}=7.82\right)$ also had a significant impact $(p=0.002)$ on the quantity of aquatic insects at the stream. Three aquatic insect orders, Diptera (most dominant), Odonata (median dominant) and Hemiptera (least dominant)], nine families and 12 genera were found occurring in the stream. Chironomus sp. (Chronomidae, 55.29\%), Brachithemis sp. and Orthetrum sp. (Libellulidae, 21.84\%) which are usually associated with polluted water showed the highest occurrence in the stream. Low values of diversity indices were observed across the six study sites, which suggest that the six sites were in unstable conditions. Site 5 has the richest (Simpson 1-D 0.77, Shannon H 1.81, Margalef 1.91) and best taxa distribution (Equitability J: 0.73), while site 3 was the poorest (Simpson 1-D 0.52 and Shannon H 1.31) and the least in taxa distribution (Equitability J 0.55).

Conclusion: This study has provided information on the assemblage and copiousness of various aquatic insects as well as the physico-chemical parameters of Aahoo stream. It could therefore be concluded that the stream could be somewhat polluted and unsafe for human consumption without being properly treated.
\end{abstract}

Keywords: Aquatic ecosystem, Diptera, Hemiptera, Odonata, Assemblage

\section{Background}

Water is the most basic natural resource needed for the survival of all living organisms in this biosphere. It plays an essential role in the maintenance of human health and aquatic ecosystem. However, the availability of good quality freshwater for various domestic, agricultural and industrial purposes in most developing countries of the world, especially Nigeria, is one of the most problematic issues facing the populace. In fact, most water bodies around the world are gradually drying out due to over-exploitation (Akindele, Adu, \& Ayandele, 2014; Martins, 2001). In Nigeria, the situation is particularly aggravated by the high level of pollution resulting from

\footnotetext{
* Correspondence: oyemmayo@gmail.com; eaoyeniyi@futa.edu.ng Department of Biology, Federal University of Technology, P. M. B. 704, Akure, Ondo state, Nigeria
}

various human activities which has further led to destruction or degradation of the aquatic ecosystem by various exotic species.

Aquatic macroinvertebrates constitute an important component of an aquatic ecosystem and they exhibit differential tolerances to changes in environmental condition. They include insects, annelids (leeches), oligochaetes (worms), crustaceans (crayfish and shrimp), molluscs (clams and mussels), and gastropods (snails) (Adu, Kemabonta, \& Giwa, 2016). Of all these groups of macroinvertebrates, the number and diversity of aquatic insects are known to be 12 times greater than other animals that share the same habitat with them, including fish, amphibans and crustaceans (Montréal, 2017).

The distribution of most aquatic insects is nevertheless influenced by several biotic and physico-chemical factors in both lentic and lotic ecosystem (Buss, Baptista, 
Nessimain, \& Egler, 2004; Payakka \& Prommi, 2014). Consequently, they are known to be very sensitive to specific changes, such as nutrient enrichment or metal pollution; some are moderate in their sensitivity to contamination while others can tolerate a wide range of contamination (Adu et al., 2016; Odume, Muller, Arimoro, \& Palmer, 2012; Wallace \& Webster, 1996).

The ability of most aquatic insects to reflect changes in their environment coupled with their high distribution when compared to other macroinvertebrates has therefore contributed to their functional role as a tool for monitoring the effect of human activity on water quality. For instance, the presence of nymphs of dragonflies, damselflies, and dobsonflies in water bodies show that the water is moderately polluted while the occurrence of midge larvae, water boatman and backswimmers (pollution-tolerant) in water bodies is a proof that it is polluted (De Moor, Day, \& De Moor, 2003).

In Nigeria, the use of aquatic insects as bioindicators for monitoring the health status of lotic aquatic ecosystem is not a common phenomenon unlike the physico-chemical approach (Arimoro \& Ikomi, 2008). Using aquatic insects as monitoring tool along with physico-chemical parameters to determine water quality has however proved to be very successful (Arimoro \& Muller, 2010; Efe, Kokoette, \& Alex, 2012). Several studies carried out by freshwater scientists within and outside the country agreed that aquatic insect community structure effectively reflects the prevailing environmental condition of aquatic environment where they inhabit (Buss et al., 2004; Arimoro \& Ikomi, 2008; Payakka \& Prommi, 2014; Prommi \& Payakka, 2015). This has therefore given impetus to the need to investigate the health status of more water bodies in Nigeria.

Aahoo stream is an important water body in Iloyin community, Akure, Southwestern Nigeria. The water quality characteristics and benthic macroinvertebrate assemblages of the stream have earlier been investigated by Adu et al. (2016). But, due to the indispensable role, the stream plays in providing water for recreational, domestic and agricultural purposes to the people of Iloyin, a more comprehensive study is needed to further establish the health status of the stream. An integrated approach which involves the use of aquatic insects and determination of physico-chemical properties of the stream was therefore employed. Consequently, the species diversity of various aquatic insects in the stream and the health status of the water body based on the aquatic entomofauna assemblages as well as the physico-chemical parameters at the study sites were investigated.

\section{Methods}

\section{Study area and sampling locations}

This study was carried out in Aahoo stream, Akure, Nigeria, from March to August 2017. Aahoo stream is located in Iloyin community between Aule village (an agrarian community) and Federal University of Technology, Akure, Ondo state. The area is surrounded by patchy forest lands, few residential buildings and several cocoa farms. The stream is the major source of water for various domestic and agricultural activities. For the purpose of this study, six study sites were selected as sampling locations (Fig. 1). All the sites were located at the littoral part of the stream since aquatic insects are predominant at the submerged and emerged vegetation. The local information peculiar to each study site based on the intensity of human disturbance and landscape are shown in Table 1.

\section{Sampling procedures}

Aquatic insects were sampled once in every fortnight using a standard aquatic D-frame hand net $(500 \mu \mathrm{m}$ mesh). Sampling of specimens at the littoral portions of the stream was carried out between the hours of $9.00 \mathrm{am}$ and $4.00 \mathrm{pm}$ on every sampling day since several studies have shown that aquatic insects were most active at those periods (Adu et al., 2016; Auta, Arimoro, Mohammed, \& Ayanwale, 2016). On each sampling day, aquatic insects were collected for $4 \mathrm{~h}$ and the sampling period at each site was $5 \mathrm{~min}$ per hour. Insect sampling was done at the hours of $9.00 \mathrm{am}, 11.00 \mathrm{am}, 1.00 \mathrm{pm}$ and $3.00 \mathrm{pm}$ respectively. Four replicate samples were collected in each sampling period, and all the insect samples from each sampling period were later pooled together replicate by replicate. Sorting and screening of aquatic insects was done by placing the samples in white trays. The aquatic insects were then handpicked from the trays using forceps while non-aquatic insects were returned into the stream. The aquatic insects per location were counted, identified and preserved in $70 \%$ ethanol. Identification of collected specimens was done to genus level using standard identification keys (De Moor et al., 2003) and a pictorial guide (Umar, Harding, \& Winterbourn, 2013).

Environmental factors that influence the abundance and assemblages of the insects at the study sites were also investigated once in every fortnight. They include $\mathrm{pH}$, ambient temperature (AT), water temperature (WT), water depth (WD) and water current velocity (WCV). Others factors are electrical conductivity (EC) and dissolved oxygen (DO) of the water. Mercury-in-glass thermometer was used for the determination of the air and water temperature of all the sites. Hanna multi-probe meter (HANNA 9828 model) was used for measuring the value of $\mathrm{pH}$, dissolved oxygen (DO), and conductivity. Water current velocity of the stream at all the sites was estimated by displacement method in which a float, a meter rule and stop clock was used over a distance of $10 \mathrm{~m}$ (Gordon, Grey, Chase, \& Simpson, 1994). Water depth was determined with the aid of 


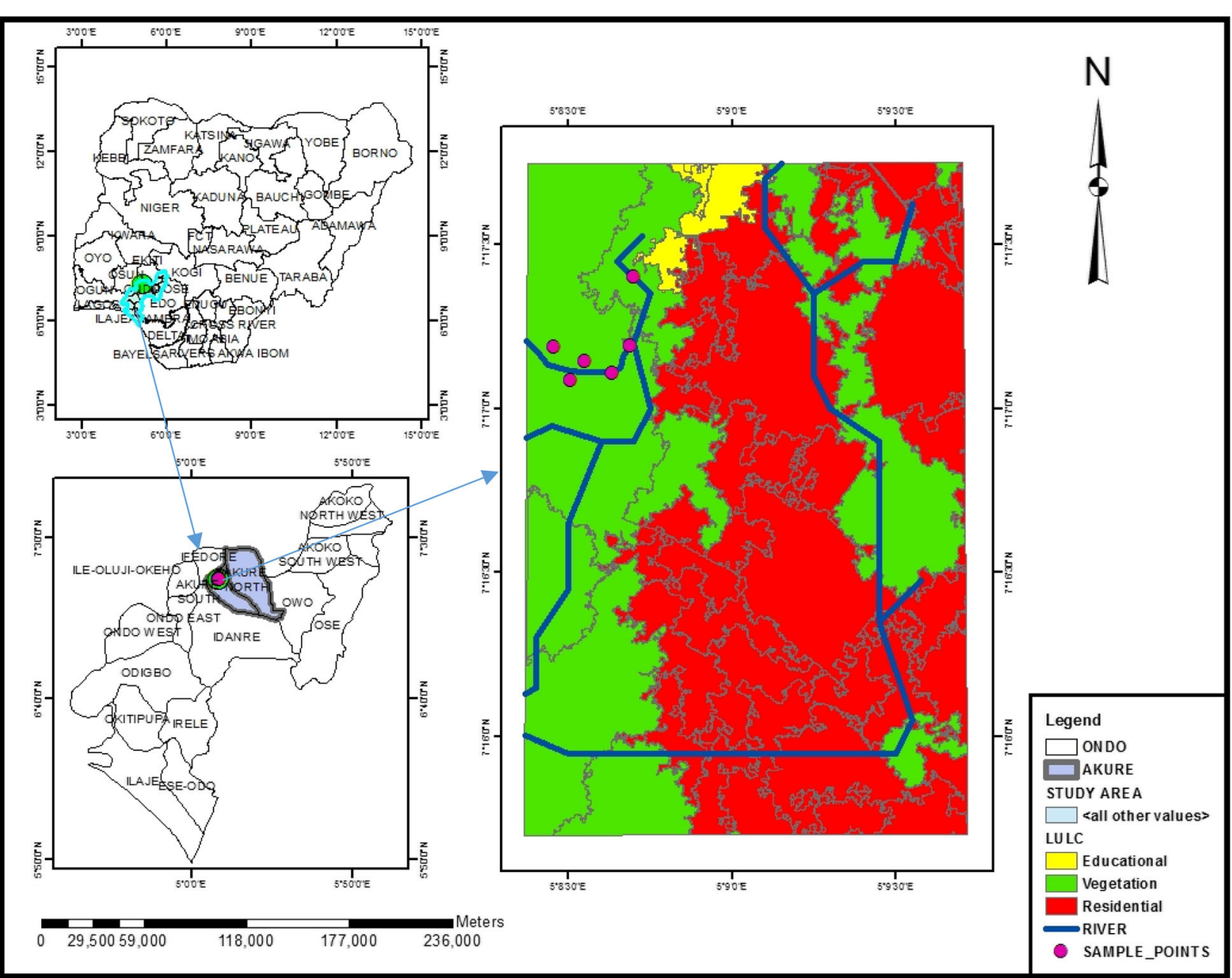

Fig. 1 Map showing the six study sites on Aahoo stream, lloyin community, Akure, Ondo state, Nigeria

calibrated rod which was dipped vertically into the stream to touch the streambed, thereafter withdrawn and then reading recorded.

\section{Analyses of data}

All data collected from the six study sites for the 6-month duration were pooled and statistically analysed using inferential and descriptive statistics. Data on physico-chemical variables were subjected to one-way analysis of variance (ANOVA) $(p<0.05)$, and where significant difference existed, means were separated using Tukey's test. ANOVA was done using SPSS 22.0 software package. Data on taxonomic composition of all the aquatic insects at the six study sites in Aahoo stream were subjected to diversity indices such as Shannon-Wiener $\left(\mathrm{H}^{\prime}\right)$, Simpson 1-D. Margalef and Equitability using Paleontological Statistical software package (PAST). All the graphs were plotted using Microsoft Excel 2013.

\section{Results}

Water quality parameters of all the six study sites at

\section{Aahoo stream}

The physico-chemical parameters of the six study sites at Aahoo stream is shown in Table 2. There was a significant effect $(p<0.0001)$ of flow rate $\left(F_{5}, 12=2221.9\right)$, electrical conductivity (EC) $\left(F_{5},{ }_{12}=276.3\right)$, air temperature $\left(F_{5,12}=110.3\right)$, water temperature $\left(F_{5,12}=\right.$ $55.5)$ and $\mathrm{pH}\left(F_{5}, 12=31.45\right)$ at the sampling sites in Aahoo stream. Similarly, there was a significant effect of water depth $\left(F_{5,12}=3.303 ; p=0.042\right)$ and dissolved oxygen (DO) $\left(F_{2,12}=7.82 ; p=0.002\right)$ at the stream irrespective of the sampling site.

The rate of water flow at site $3(0.41 \mathrm{~m} / \mathrm{s})$ and $4(0.42$ $\mathrm{m} / \mathrm{s})$ was significantly faster $(p<0.05)$ when compared to the remaining sites. Highest EC was observed in site $6(734.30 \mu \mathrm{S} / \mathrm{cm})$ and this was significantly higher $(p<0.05)$ than the EC of all the remaining sites. The 


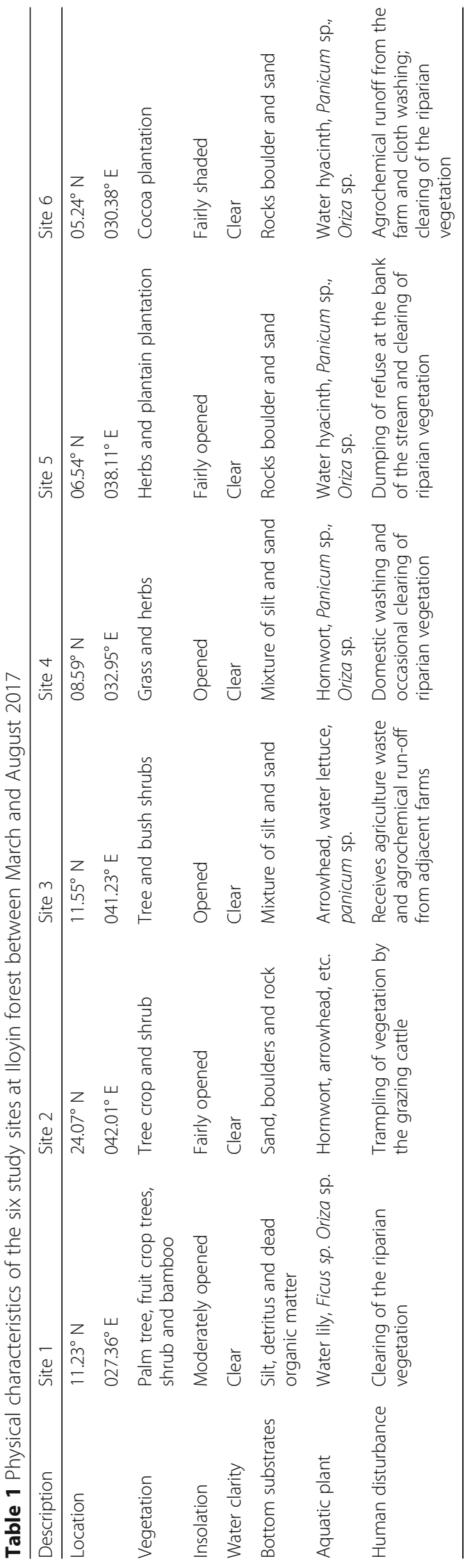


Table 2 The physico-chemical parameters of the six study sites at Aahoo stream, Akure, Nigeria

\begin{tabular}{llllllll}
\hline Site & Flow rate $(\mathrm{m} / \mathrm{s})$ & $\mathrm{EC}(\mu \mathrm{S} / \mathrm{cm})$ & Air temp $\left({ }^{\circ} \mathrm{C}\right)$ & Water temp $\left({ }^{\circ} \mathrm{C}\right)$ & $\mathrm{pH}$ & Water depth $(\mathrm{m})$ & $\mathrm{DO}(\mathrm{mg} / \mathrm{L})$ \\
\hline 1 & $0.40 \pm 0.06 \mathrm{~b}$ & $617 \pm 5.03 \mathrm{a}$ & $29.3 \pm 0.33 \mathrm{a}$ & $27.3 \pm 0.33 \mathrm{a}$ & $7.03 \pm 0.03 \mathrm{c}$ & $0.33 \pm 0.01 \mathrm{a}$ & $5.14 \pm 0.01 \mathrm{~b}$ \\
2 & $0.06 \pm 0.001 \mathrm{a}$ & $673 \pm 2.0 \mathrm{~b}$ & $33.7 \pm 0.33 \mathrm{~b}$ & $30.07 \pm 0.07 \mathrm{~b}$ & $6.1 \pm 0.1 \mathrm{a}$ & $0.35 \pm 0.02 \mathrm{a}$ & $5.08 \pm 0.00 \mathrm{ab}$ \\
3 & $0.41 \pm 0.01 \mathrm{~b}$ & $627.3 \pm 2.1 \mathrm{a}$ & $28.26 \pm 0.1 \mathrm{a}$ & $27.35 \pm 0.22 \mathrm{a}$ & $6.4 \pm 0.1 \mathrm{~b}$ & $0.35 \pm 0.01 \mathrm{a}$ & $5.13 \pm 0.00 \mathrm{~b}$ \\
4 & $0.42 \pm 0.01 \mathrm{~b}$ & $626.3 \pm 2.1 \mathrm{a}$ & $28.25 \pm 0.1 \mathrm{a}$ & $27.34 \pm 0.22 \mathrm{a}$ & $6.5 \pm 0.1 \mathrm{~b}$ & $0.35 \pm 0.01 \mathrm{a}$ & $5.13 \pm 0.00 \mathrm{~b}$ \\
5 & $0.06 \pm 0.001 \mathrm{a}$ & $692 \pm 2.8 \mathrm{c}$ & $32.9 \pm 0.32 \mathrm{~b}$ & $29.81 \pm 0.09 \mathrm{~b}$ & $7.07 \pm 0.7 \mathrm{c}$ & $0.31 \pm 0.003 \mathrm{a}$ & $5.05 \pm 0.03 \mathrm{a}$ \\
6 & $0.06 \pm 0.001 \mathrm{a}$ & $734.3 \pm 1.2 \mathrm{~d}$ & $33.12 \pm 0.11 \mathrm{~b}$ & $30.22 \pm 0.11 \mathrm{~b}$ & $7.2 \pm 0.03 \mathrm{c}$ & $0.34 \pm 0.003 \mathrm{a}$ & $5.14 \pm 0.01 \mathrm{~b}$
\end{tabular}

Means followed by the same letter within the column are not significantly different $(p>0.05)$ using Tukey's test

$E C$ electrical conductivity, $D O$ dissolved oxygen

air and water temperature at sites 2,5 and 6 were significantly higher $(p<0.05)$ than that of their counterpart in sites 1,3 and 4 respectively. No significant difference $(p>0.05)$ existed in the depth of the stream at all the sampling sites. The dissolved oxygen at sites 1 and 6 was significantly higher $(p<0.05)$ than those of sites 2 and 5.

\section{Assemblages and distribution of aquatic insects in Aahoo stream}

Table 3 presents the checklist of aquatic insects occurring in the stream. A total of 1456 aquatic insects which comprises of 12 genera in nine families and three orders were collected at the six study sites. Study sites 3 and 4 had 11 taxa, site 2 had 10 , site 1 had 9 , while site 6 had

Table 3 Checklist of aquatic insects' occurrence at the six study sites at Aahoo stream, Akure, Nigeria

\begin{tabular}{|c|c|c|c|c|c|c|c|c|}
\hline Taxa & Site 1 & Site 2 & Site 3 & Site 4 & Site 5 & Site 6 & Total & $\%$ Occurrence \\
\hline \multicolumn{9}{|l|}{ Odonata $^{1}$} \\
\hline \multicolumn{9}{|l|}{ Gomphidae ${ }^{2}$} \\
\hline Lestinogomphus $^{3}$ & 3 & 18 & 12 & 9 & 8 & 0 & 50 & 3.43 \\
\hline \multicolumn{9}{|l|}{ Libelilludae $^{2}$} \\
\hline Brachithemis $^{3}$ & 6 & 31 & 18 & 35 & 56 & 27 & 173 & 11.88 \\
\hline Orthetrum $^{3}$ & 8 & 26 & 15 & 27 & 49 & 20 & 145 & 9.96 \\
\hline \multicolumn{9}{|l|}{ Coenagrionidae $^{2}$} \\
\hline Ceriagrion $^{3}$ & 0 & 0 & 7 & 17 & 36 & 18 & 78 & 5.36 \\
\hline \multicolumn{9}{|l|}{ Pseudagrionidae ${ }^{2}$} \\
\hline Pseudagrion $^{3}$ & 6 & 8 & 4 & 8 & 14 & 6 & 46 & 3.16 \\
\hline \multicolumn{9}{|l|}{ Diptera $^{1}$} \\
\hline \multicolumn{9}{|l|}{ Chironomidae $^{2}$} \\
\hline Chironomous $^{3}$ & 74 & 142 & 189 & 163 & 125 & 112 & 805 & 55.29 \\
\hline \multicolumn{9}{|l|}{ Tabanidae $^{2}$} \\
\hline Tabanus $^{3}$ & 0 & 0 & 5 & 7 & 6 & 0 & 18 & 1.24 \\
\hline \multicolumn{9}{|l|}{ Cucilidae $^{2}$} \\
\hline Anopheles $^{3}$ & 7 & 4 & 8 & 6 & 4 & 6 & 35 & 2.40 \\
\hline Culex $^{3}$ & 11 & 4 & 7 & 7 & 8 & 5 & 42 & 2.88 \\
\hline \multicolumn{9}{|l|}{ Hemiptera' } \\
\hline \multicolumn{9}{|l|}{ Nepidae $^{2}$} \\
\hline Ranatra ${ }^{3}$ & 6 & 9 & 4 & 0 & 4 & 0 & 23 & 1.58 \\
\hline $\mathrm{Nepa}^{3}$ & 5 & 6 & 7 & 3 & 4 & 4 & 29 & 1.99 \\
\hline \multicolumn{9}{|l|}{ Naucoridae $^{2}$} \\
\hline Ilyocoris $^{3}$ & 0 & 6 & 0 & 4 & 2 & 0 & 12 & 0.82 \\
\hline Total & 126 & 254 & 276 & 286 & 316 & 198 & 1456 & 100 \\
\hline
\end{tabular}


the least number of taxa (8), which shows that more than half of the taxa sampled were found occurring at all the study sites. Only site 5 contained all the taxa encountered in the stream. The highest number of individuals was also observed in site 5 while the least was observed in site 1 .

Diptera accounted for the largest number of individuals (900), and it was represented by three families (Chironomidae 805; Cucilidae 77 and Tabanidae 18). Diptera is followed by Odonata (492) which is represented by four families (Gomphidae 50; Libelullidae 318; Coenagrionidae 78; Pseudagrionidae 46). The taxon with the least number of individuals is Hemiptera (64), and it is also represented by two families (Nepidae 52 and Naucoridae 12$)$. The highest $(55.29 \%)$ and least $(0.82 \%)$ relative percentage abundance was shown by Chironomus (Chironomidae) and Ilyocoris (Naucoridae), respectively, of all the taxonomic groups of aquatic insects sampled for the period of study at Iloyin stream (Fig. 2). Other taxonomic groups such as Brachithemis (Libelullidae) (11.88\%), Orthetrum (Libelullidae) (9.96\%), Ceriagrion (Coenagrionidae) (5.36\%), Lestinogomphus (Gomphidae) (3.43\%), Pseudagrion (Pseudagronidae) (3.16\%), Culex (Culicidae) (2.88\%), Anopheles (Culicidae) (2.40\%), Nepa (Nepidae) (1.99\%), Ranatra (Nepidae) (1.58\%) and Tabanus (Tabanidae) (1.24\%) were observed for the 6-month period of the study at the stream (Fig. 2).

The cluster analysis based on the Jaccard Index showed differences in taxa composition between the six study sites and separated them into four groups based on percentage of similarity (92\%, 83\%, 75\% and 76\%) (Fig. 3). The difference and dissimilarity in organisms sampled in the six sites increased with increase in height (distance). Ninety-two percent (92\%) similarity was observed among the genera of aquatic insects found in sites 1 and 2, 3 and 5 as well as 4 and 5. However, 83\% similarity was observed among the genera of aquatic insects found in sites 1 and 3, 2 and 5, as well as 3 and 4 . Four paired sites ( 1 and 5, 2 and 3, 2 and 4, as well as 4 and 5) had $75 \%$ of the genera sampled at the stream to be similar. Jaccard similarity index also revealed that $67 \%$ of genera sampled in study sites 1 and 4, as well as 5 and 6 , were similar.

\section{Richness and diversity of taxa in Aahoo stream}

Table 4 presents the diversity of aquatic insect community at Aahoo stream. Highest diversity indices (Simpson 1-D 0.77 and Shannon H 1.81, Margalef 1.91) and Equitability J (0.73) was observed in site 5 of all the sites sampled in this study. Study site 3 has the least diversity indices values (Simpson 1-D 0.52 and Shannon H 1.31). The value of the Equitability J index also shows that the taxa occurring at site 3 are not well distributed.

\section{Discussion}

The physico-chemical characteristics of the stream at all the six study sites were observed to be significantly different from each other with the exception of water depth. All the parameters observed in this study have been previously used for the assessment of water quality in Nigeria (Adefemi, Asaolu, \& Olaofe, 2007; Adu et al., 2016; Auta et al., 2016). High flow rate of water observed at sites 1,3 and 4 may be attributed to the absence of congested rocks and sand in each of these sites when compared to sites 2,5 and 6 which were characterised with rocks, sands and boulders. The reduction in

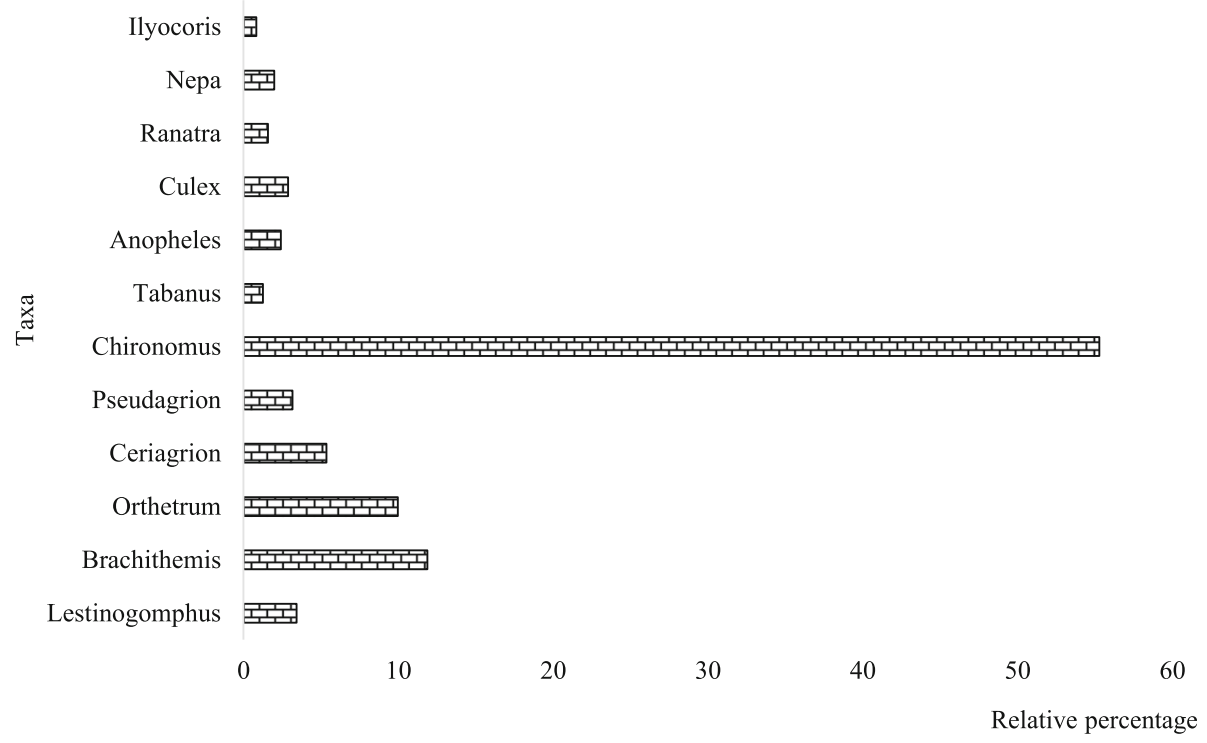

Fig. 2 The relative percentage of aquatic insects per genus, from March to August 2017, in Aahoo stream, Akure, Nigeria 


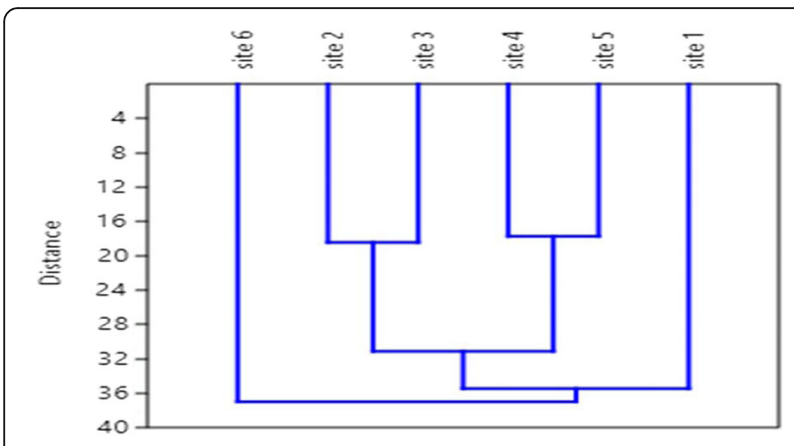

Fig. 3 Dendrogram illustrating similarities in aquatic insect assemblages between the six study sites

water velocity at sites 2,5 and 6 may also be attributed to the invasiveness of the aquatic plants such as Azolla africana, Oriza spp. and Echinochloa spp. at each of these sites in Aahoo stream. Although all the electrical conductivity (EC) values recorded for all the six study sites fall within the recommended value for freshwater life according to World Health Organization (WHO, 1984) standard $(<1000 \mu \mathrm{S} / \mathrm{cm})$ (Chapman \& Kimstach, 1996), it is noteworthy to know that the EC values recorded for all the sites were still high $(>600 \mu \mathrm{S} / \mathrm{cm})$ when compared to what have been reported by Egborge (1994) for many freshwaters $(<500 \mu \mathrm{S} / \mathrm{cm})$. Higher EC values have earlier been reported as an indication of somewhat polluted water (Oben, 2000).

Similarly, temperature plays important roles in the determination of dissolved oxygen (DO) concentration in freshwater habitat. Warm water has been reported to have a low concentration of dissolved oxygen (Corbet, 2004). Other factors that determine DO values include salinity, turbulence, and shadiness of streams (Chapman \& Kimstach, 1996). The DO concentration in this study falls within the range of 5.00 to $10.00 \mathrm{mg} / \mathrm{L}$ which is good for many aquatic organisms. Water $\mathrm{pH}$ plays a significant role in influencing many biological and chemical activities in freshwater bodies. For instance, low $\mathrm{pH}$ value increases the solubility of metals; it could also serve as an indication of increased nutrient for aquatic organisms. The $\mathrm{pH}$ values recorded in all the sites are within the recommended range of 6.0 to 8.5 for standard

Table 4 Diversity of aquatic insects' community in Aahoo stream, Iloyin, Akure

\begin{tabular}{lllllll}
\hline & Site 1 & Site 2 & Site 3 & Site 4 & Site 5 & Site 6 \\
\hline Taxa & 9 & 10 & 11 & 11 & 12 & 8 \\
Individuals & 126 & 254 & 276 & 286 & 316 & 198 \\
Simpson_1-D & 0.6314 & 0.6532 & 0.5185 & 0.644 & 0.771 & 0.6401 \\
Shannon_H & 1.513 & 1.538 & 1.31 & 1.547 & 1.807 & 1.427 \\
Margalef & 1.654 & 1.625 & 1.779 & 1.768 & 1.911 & 1.324 \\
Equitability_J & 0.689 & 0.668 & 0.546 & 0.645 & 0.727 & 0.686 \\
\hline
\end{tabular}

freshwater life (Chapman \& Kimstach, 1996). All the values of physico-chemical parameters sampled in this study were consistent with what have been previously reported by Adu et al. (2016).

Aquatic insects are usually the dominant macroinvertebrates in freshwater bodies. Studies have shown that different taxa of macroinvertebrates including aquatic insect respond differently to various types of pollution, an attribute that is responsible for their functional role as an indicator of water quality (Odume et al., 2012; Wallace \& Webster, 1996). The assemblage of aquatic insect in Aahoo stream revealed that Diptera was the most dominant taxon observed in this study. This is in agreement with the findings of Ikomi and Arimoro (2014) where Diptera was observed to dominate the aquatic insect taxa sampled at Ethiope River, Niger Delta, Nigeria. Chironomous species was the only member of the Chironomidae recorded at Aahoo stream and it showed the highest numerical abundance of all the Diptera sampled in this study irrespective of the study sites. Coffman and Ferrington (1984) had earlier reported Chironomidae as the dominant group of benthic macroinvertebrate fauna of stream, both in numerical abundance and species richness. The sensitive ones such as Polypedilum and Clinotanypus species were not sampled at the stream throughout the sampling period. The presence of Chironomous species in large number in all the six sampling sites suggests that the water in Aahoo stream could be slightly polluted. A similar observation has been reported by De Moor et al. (2003) as well as Ikomi and Arimoro (2014).

Odonata was next to Dipterans in terms of abundance and were all represented at the six sites except Ceriagrion (Coenagrionidae) which was not sampled at sites 1 and 2 and Lestinogomphus (Gomphidae) which was absent in site 6. Generally, odonates are somewhat tolerant to pollution, while the Gomphidae can thrive in heavily polluted water. All the odonates sampled at the stream were eurytopic species which can thrive in a disturbed environment. Ilyocoris species (Naucoridae) was found to have the least numerical abundance in Aahoo stream. The paucity of this taxon was unexpected since they are known to have the ability to adapt to changing environmental factors (Gelbic, Papacek, \& Pokuta, 1994).

Javaid and Ashok (2013) had earlier opined that Shannon-Wiener diversity values ranging from 1 to 2 indicate moderately polluted water. In this study, most of the diversity indices values obtained across the six study sites ranged from 1.31 to 1.81 , and this further corroborates the earlier observations that Aahoo stream is somewhat polluted. A similar observation had earlier been reported by Adu et al. (2016) for macroinvertebrates in Aahoo stream. Simpson diversity index value recorded for the six sites however have a range of 0.52 
to 0.77 which falls somewhat within the range for the stable environmental condition of 0.6 to 0.9 (Dash, 2003). Also, site 5 showed the richest and best taxa distribution when compared to other sites while site 3 had the least taxa distribution. The least taxa distribution observed in site 3 clearly demonstrated that this is the most polluted of all the sampled sites. Highest numerical abundance of Chironomous species observed in site 3 further showed that the site is polluted, and this may be linked to various agricultural waste and chemical run-off from a cocoa plantation in this area.

\section{Conclusion}

The study revealed that Aahoo stream is somewhat polluted based on data on physico-chemical water quality and the entomofauna composition. This is evidenced by the collection of assemblages of chironomids in the stream which are tolerant to polluted water. Also, all Odonata taxa collected were the eurytopic types which could thrive in polluted water. Lestinogomphus (Gomphidae), an odonate associated with heavily polluted water, was also among the Odonata representatives at the stream; although few organisms from this genus were sampled at the stream. To complement the biotic data, physico-chemical conditions of the stream also suggest that the stream is somewhat polluted.

\section{Abbreviations}

ANOVA: Analysis of variance; AT: Ambient temperature; DO: Dissolved oxygen; EC: Electrical conductivity; WCV: Water current velocity; WD: Water depth; WHO: World Health Organization; WT: Water temperature

\section{Acknowledgements}

The researchers want to appreciate Mr. Giwa E. O for his assistance during the field work

\section{Funding}

The research work was self-funded.

\section{Availability of data and materials}

Data sharing not applicable to this article as no datasets were generated or analyzed during the current study.

\section{Authors' contributions}

BWA conceived and designed the study. BWA and EAO collected the data and carried out the analysis. BWA and EAO wrote the manuscript. Both authors read and approved the manuscript.

Ethics approval and consent to participate

Not applicable

\section{Consent for publication}

Not applicable

\section{Competing interests}

The authors declare that they have no competing interests.

\section{Publisher's Note}

Springer Nature remains neutral with regard to jurisdictional claims in published maps and institutional affiliations.
Received: 24 October 2018 Accepted: 13 February 2019

Published online: 28 February 2019

\section{References}

Adefemi, O. S., Asaolu, S. S., \& Olaofe, O. (2007). Assessment of the physicochemical status of water samples from major dams in Ekiti State, Nigeria. Pakistan Journal of Nutrition, 6(6), 657-659.

Adu, B. W., Kemabonta, K. A., \& Giwa, O. E. (2016). Study of water quality characteristics and benthic macroinvertebrate assemblages of Aahoo stream, Akure, southwestern Nigeria. Nigeria Journal of Scientific Research, 15(3), 499-504.

Akindele, E. O., Adu, B. W., \& Ayandele, M. A. (2014). Hydrology and water quality characteristics of a stressed lotic freshwater system in southwest Nigeria. Tropical Freshwater Biology, 23, 1-19.

Arimoro, F. O., \& Ikomi, R. B. (2008). Response of macroinvertebrates to abattoir wastes and other anthropogenic activities in a municipal stream in the Niger Delta, Nigeria. Environmentalist, 28, 85-98.

Arimoro, F. O., \& Muller, W. J. (2010). Mayfly (Insecta: Ephemeroptera) community structure as an indicator of the ecological status of a stream in the Niger Delta area of Nigeria. Environmental Monitoring Assessment, $166,581-594$.

Auta, Y. I., Arimoro, F. O., Mohammed, A. Z., \& Ayanwale, A. V. (2016). Monitoring seasonal changes in environmental variables and Chironomid diversity at Shiroro Lake, Niger state, Nigeria. International Journal of Applied Biological Research, 7(1), 36-47.

Buss, D. F., Baptista, D. F., Nessimain, J. L., \& Egler, M. (2004). Substrate specificity, environmental degradation and disturbance structuring macroinvertebrate assemblages in neotropical streams. Hydrobiologia, 518(1-3), 179-188.

Chapman, D., \& Kimstach, V. (1996). Selection of water quality variables. Water quality assessments: A guide to the use of biota, sediments and water in environment monitoring, Chapman Edition, (2nd ed., pp. 59-126). London: E and FN Spon. https://doi.org/10.4324/noe0419216001.ch3.

Coffman, W. P., \& Ferrington, J. L. C. (1984). Chironomidae. In R. W. Merritt, \& R. W. Cummins (Eds.), An introduction to the aquatic insects of North America, (2nd ed., pp. 551-652). Dubuque: Kendall-Hunt Publishing Co..

Corbet, P. S. (2004). Dragonflies: behaviour and ecology of Odonata, (p. 829). Colchester: Herley Books.

Dash, M. C. (2003). Fundamental of ecology, (3rd ed., p. 563). New Delhi: Tata McGraw-Hill Publishing Company Limited.

De Moor, I. J., Day, J. A., \& De Moor, F. C. (2003). Guides to the freshwater invertebrates of Southern Africa, vol. 7. In Insecta 1 (Ephemeroptera, Odonata and Plecoptera) TT, (p. 300). Pretoria: Water Research Commission.

Efe, O., Kokoette, E. I., \& Alex, U. A. A. (2012). Physico-chemical parameters and benthic macroinvertebrates of Ogunpa river at Bodija, Ibadan, Oyo State. European Journal of Scientific Research, 85(1), 89-97.

Egborge, A.B.M. (1994) Water pollution in Nigeria: Biodiversity and chemistry of Warri river, Ben Miller Books, Warri. 1, 331.

Gelbic, I., Papacek, M., \& Pokuta, J. (1994). The effects of methroprenes S on the aquatic bug Ilyocoris cimicoides (Hemiptera Naucoridae). Ecotoxicology, 3, 89-93.

Gordon, D. M., Grey, K. A., Chase, S. C., \& Simpson, C. O. J. (1994). Changes to the structure and productivity of a Posidonia sinuosa meadow during and after imposed shading. Aquatic Botany, 47, 265-275.

Ikomi, R. B., \& Arimoro, F. O. (2014). Effects of recreational activities on the littoral macroinvertebrates of Ethiope River, Niger Delta. Nigeria Journal of Aquatic Science, 29(1B), 155-170.

Javaid, A. S., \& Ashok, K. P. (2013). Application of diversity indices to crustacean community of Wular Lake, Kashmir Himalaya. International Journal of Biodiversity and Conservation, 5(6), 311-316.

Martins, O. (2001). Water resources management and development in Nigeria Issues and challenges in a new millenium. In An inaugural lecture delivered at the University of Agriculture, Abeokuta on Wednesday, 22nd of August, 2001, (pp. 1-62)

Montréal, V.D. (2017). Insects and Other Arthropods: Aquatic insects http:// espacepourlavie.ca/en/aquatic-insects (Retrieved 8 Nov 2017).

Oben, B. O. (2000). Limnological assessment of the impact of agricultural and domestic effluent on three man-made lakes in Ibadan, Nigeria. PhD thesis. Nigeria: University of Ibadan.

Odume, O. N., Muller, W. J., Arimoro, F. O., \& Palmer, C. G. (2012). The impact of water quality deterioration on macroinvertebrate communities in Swartkops 
River, South Africa: A multimetric approach. African Journal of Aquatic Science, 37, 191-200.

Payakka, A., \& Prommi, T. (2014). Aquatic insects biodiversity and water quality parameters of receiving water body. Current World Environment Journal, 9(1), $53-58$.

Prommi, T., \& Payakka, A. (2015). Aquatic insect biodiversity and water quality parameters of streams in Northern Thailand. Sains Malaysiana 44(5), 707-717.

Umar, D. M., Harding, J. S., \& Winterbourn, M. J. (2013). Freshwater invertebrates of the Mambilla Plateau, Nigeria, (p. 88). New Zealand: Photographic Guide School of Biological Sciences University of Canterbury.

Wallace, J. B., \& Webster, J. R. (1996). The role of macroinvertebrates in stream ecosystem function. Annual Review of Entomology, 41(1), 115-139. https://doi. org/10.1146/annurev.en.41.010196.000555.

WHO (World Health Organization) (1984). International Standard for Drinking Water, (4th Ed). Geneva: WHO Press, World Health Organization. pp. 327.

\section{Submit your manuscript to a SpringerOpen ${ }^{\circ}$ journal and benefit from:}

- Convenient online submission

- Rigorous peer review

- Open access: articles freely available online

- High visibility within the field

- Retaining the copyright to your article

Submit your next manuscript at $\boldsymbol{\nabla}$ springeropen.com 